\title{
Effectiveness and/or equity in the education system in Romania. A comparative analysis
}

\author{
Gabriela Neagu \\ Research Institute for Quality of Life, Romania \\ gabi.neagu@iccv.ro
}

DOI:10.5901/mjss.2014.v5n22p493

\begin{abstract}
The most importnat objectives of education systems aim to ensure equity and equal opportunities in education for all members of society and the highest level of effectiveness of education. So far no education system can not support it achieved these goals some are closer, others far removed from their achievement. Also, although the ideal would be for a high level of effectiveness is associated with a high degree of equity and equality before education for all members of society, in reality, there are many situations where equity and efficiency not found in the same education system. In this paper we propose to determine the position and situation of the education system in Romania in terms of efficiency, equity and equality in the face of education. For this, we use a set of indicators and results of various national and international assessment tests attended and Romanian students.
\end{abstract}

Keywords: system of indicators, equity, efficiency, equality, PISA

\section{Introduction}

Public education history, is the earth and the history of concerns to find solutions through which education systems to become equity and efficiency for all members of society they belong to. The nearly two centuries of common history have not been sufficient to resolve this problem since no education system can hardly claim has identified a solution or a way to become equity and efficiency for all. On the other hand, as the degree of complexity of the society in general and of the systems of education in particular has increased, equity and efficiency in education have become two objectives implementation of which seems more and more distant.

Between his satisfaction seeking a "solution-miracle" - democratization of education at all levels - and disheartening conclusion of Bourdieu's - school, place of social breeding (P. Bourdieu apud Mahler, 1975), there are countless theories, perspectives of analysis, proposals for the reduction of disparities between individuals, groups or individuals as regards equity and efficiency in education etc.

According to the context of socio-economic, political, cultural etc. some education systems have managed to achieve a high level of equity and/or the efficiency of while others have still big problems to ensure a minimum level of education for all members of society.

Between inequitable/ineffective absolute - equity/efficiency full, education systems occupy different positions. Setting as much as possible in the position he occupies a system of education in relation to both its own targets and by comparison with the other systems in this range requires an integrated approach developed and complex.

\section{Method}

Theme equity and efficiency in education may be analyzed by means of both the call to quantitative methods and qualitative methods. Given the objective set out but also data which we have we will call to the analysis of secondary data.

Secondary analysis of quantitative data is a method of research frequently used and which shall consist of the analysis of the data from previous research which have had their problems in the center of education in general and on the equity and efficiency of education, in particular. 


\section{Materials}

A number of important institutions, national or international are concerned and shall have the authority to collect and process data relating to education systems: UNESCO, EUROSTAT, Eurydice etc. In the case at hand, in order to carry out a comparative analysis between the education system in Romania and other education systems from the perspective European equity and effectiveness in education we are going to appeal to the data provided by the OECD by international research PISA $(2000,2009)$ but also to those published by Eurostat or Eurydice.

\section{Procedure}

Setting the level of equity and efficiency in the level of a system of education assumes existence of units of measurement - measurement of indicators of equity and efficiency in education. History of drawing up a system of indicators to measure the equity and efficiency of the education system is one of the more recent but no less complex than that of education itself. Therefore I considered it necessary to a presentation of the main systems of indicators of education proposed by international institutions or the national.

For the systems of education in western societies, the publication in 1973 by OECD of the document "A system of indicators of orientation of education aimed at making public power" (Bottani, 2008:12) is the start of a process developed and time consuming to build a lens system, based on scientific criteria for the evaluation, as possible to be applied as many education systems in the world other than that the structure, organization, context in which activities are carried out etc. In 1992, OECD published first assembly of indicators of of the educational system. OECD publication "Education at a Glace" is the document key of the organization and in the present. First edition of the work, published in English and French contains 38 indicators grouped on the following areas: might drop, context socio-economic costs of education, human resources, participation in education, the system decision-making, students' results, system outcomes, the relationship with the market. Over time, OECD and improved technique for the collection of data, methods of calculation of indicators and continued to publish each year an edition of this report, which includes data on education systems of the Member States of the organization. The best result of the OECD in any steps taken in the course of time to establish a coherent framework, founded the scientific evaluation of the systems of education program is PISA.

PISA - Programme for International Student Assessement - is a program for the evaluation which shall be conducted once every three years, in more than 60 countries of the world. Romania being included in the year 2000 in this program. Evaluation is carried out on a representative sample of students under the age of 15 years, in the subjects reading, mathematics and science.

The results obtained as a result of collecting the data and processing of them let you carry out a

basic profile of knowledge held by students but also data concerning the general situation of the educational system in a country. On the basis of these results a system of education in a country may assess the situation not only by comparison with its own targets, but compared with the situation of education systems in the other participating countries.

OECD this is not the only interested in the evaluation of education systems. Eurydice, UNDP, UNESCO, etc. are also organizations which have developed rating systems complex, from which it is frequently used to analyze the situation of a system of education in a country or in comparative perspective, more as regards equity and effectiveness in education.

UNDP is an organization which published in 1990 a report on Human Development in which are to be found data and about education, which is considered to be one of the factors very important development of all the companies. Between the UNDP indicators used to calculate the index human development include: literacy rate adult; gross rate of poor education, expenditure on education; use of the Internet; average duration of education. (http://hdr.undp.org/fr/statistiques/idh/)

UNESCO is the organization which, since its establishment in 1945, established that education should be considered as priority area. Within the organization there is a Department for Education made up of six institutes and two centers which focuses on this area with the aim of aiding all states to overcome the difficulties encountered in problems related to the education of citizens. The result of this department is concentrated in an annual report - Education for all (EPT) - in which it is assessed the situation of education systems in most countries world. Exception to this are countries in conflict or post where an opportunity to collect any data and their objectivity is very low.In the context of the report there is an emphasis on four issues considered to be of main importance: universalizing primary education; literacy rate of adults (people aged 15 years and over); equality of sex in front of education; quality education. On the basis of these indicators is calculated the 
index develop education for all (IDE), a composite index that provides an overall picture, objective on the system of education in a country. Index value is between 0 and 1.1 means the making of full four objectives. (www.unesco.org).

Although EU countries are also included in the system of indicators of the OECD but also the drawn up at the UNESCO and UNDP, it is considered necessary to develop a system of evaluation of education in which they are listed first European states.

Eurydice is the description of a dedicated network systems of education in Europe and that its main objective the "providing all the persons responsible for the systems of education or in the area of education analysis and information at the European level to assist in the decision making process"(http://eacea.ec.europa.eu/education/eurydice/about_eurydice_fr.php). In 2007 Eurydice is an integral part of the program of action in the field of European education and lifelong learning. To ensure comparability data supplied Eurydice shall cooperate with international organizations, such as UNESCO, OECD but also with other institutions and structures for at the European level. Data about education are grouped into 121 of indicators that cover the following areas:context in which it operates the education system; the structures of the educational system; school participation (participation rate school on different levels of education, mobility educational); system resources education; educational processes; graduates and levels of training. The publication of the reference Eurydice network is "Key data on Education".

In 2005, a multidisciplinary team made up of teachers and researchers from universities and research centers have collaborated to develop an international system of indicators of equity and equality in education systems in the EU, in the framework of a project supported by the European Commission through the program Socrates 6.1.2.(Hutmacher et Bottani, coord. GERESE, 2005 )

The project has been carried out within the framework of the Group of European Research Equity Education Systems GERESE. As we said in the report published by GERESE goal of this project was not only to measure and compare fairness and equality of European education systems, but also to build a useful tool decision makers who are responsible for the education policies of these countries.(Hutmacher et Bottani, coord.2005)

The system developed by the team comprises a number of 29 of indicators grouped on two dimensions. First dimension focuses on individuals between which may occur different forms of inequality in the face of education. For their evaluation have been build 15 indicators which measure differences/disparities between individuals, disparities between groups/categories of individuals and the weighting population located below the minimum threshold of powers. (Hutmacher et Bottani, coord. 2005:9)The second dimension, where are your focus remaining 14 indicators, cover differences which may arise in the fields of education, socio-economic context in which they operate the education system, the process advisory-educational internal results of the educational system and the results of its foreign affairs. Until these indicators system is the first to address problem explicitly equity in education and proposes to a measure of comparative perspective between more education systems.

In addition to international instruments by which it can be evaluated the system(s) of education, many countries have established their own systems with measurement/evaluation. Romania is no exception.

In 2005, a team of Romanian researchers in the area of education has drawn up a national System of Indicators for Education (SNIE) which is compatible with European statistical system built by EUROSTAT. Like other systems, assessment tools, measurement and SNIE, has been created in order to support the authorities in the evaluation of the educational system but, in equal measure, it is addressed to all those involved in the field. The system uses different sources of data - exhaustive surveys on education units, AMIGO, surveys on continuing vocational training (FORPRO), investigation carried out by UNESCO, OECD and Eurostat through a questionnaire UOE representing a system of collection of data from different countries(Bârzea, coord.2005: 14) In 2005, the report on the state of the educational system document drawn up annually by the authorities in the industry - the use of this assessment tool.

The system is structured on the following components (Barzea, coord.2005): context education ;access and participation in education and training;quality and efficiency of education and training; the results of the educational system, and the results of education and training.

For the purpose of these systems of indicators is to permit comparisons both between education systems as well as inside systems on different components, we notice that the same indicators or the same dimensions are to be found in at least two of them or even in all. The option for a system or another of indicators depends on the lens that he proposes the assessor, the data at its disposal. In this article we will use those indicators which reveals complementarity of the two dimensions undergoing analysis: equity and efficiency in education. 
In general terms, equity in education is defined as "to give each of them what- must be" (Herbaut, 2011:53). Measurement difficulty equity in education comes from that, it should be laid down which needs of individuals in the field of education.

For the determination of this type the persons responsible for the needs of the education system but also researchers must take into account both of their interests, the possibilities for individuals as well as the current requirements and the prospect of the economy and society. Thus, the interests and the possibilities individuals of education must not be influenced by their social origin, membership of majority or from an ethnic minority, religious, etc. On the other hand, if in a few decades the ability to write and read was sufficient for socio-economic integration of the individual, at present only of holding these powers exposed individuals at risk of social marginalisation. In a society and a knowledge-based economy equity in education tends to extend including forms of continuing education. In other words, equity in education affects both what is going on with the guy inside the system - internal equity - as well as on the edges of external equity.

A equity system of education is considered that system "qui traite tous les éléves comme des égaux et qui vise à favoriser une société équitable, dans laquelle les biens essentiales sont distribuiés conformeéent aux règles de la justice et qui favorise la coopération sur pied d'égalité"(Hutmacher et Bottani, coord.2005:12) To determine how many equitably is a system of compulsory education are used indicators such as: the percentage students located below the minimum knowledge, school participation rate depending on the environment of residence, employment rate of the population as a function of the level of education attained etc.

In the early 60s two economists Americans - G. Beker and Th. Schultz - they've changed definitively perception of education: from consumer, education becomes a good investment. (Becker, 1997) The society but also the individual human being allocated time and money to the school in order to obtain benefits: the raising of the standard of living, improve the state of health and family life, getting a job a better paid job and safer, directing an positions socio-professional high etc. Efficiency of the educational system is, as a general rule, evaluation of the balance between investments of society and the individual and benefits obtained. As in the case of equity and effectiveness of the education system is the internal and external nature. For the measurement of effectiveness, traditionally use the indicators as well as school abandon rate, the rate of transition from one level to another of education, "the effect school" on the results of the students at different national and international testing etc. For external evaluation of the effectiveness of the educational system of attention is focused on the impact on the evolution of social educational and professional, the individual but also of the members of the family, the community to which it belongs: young people who are not covered by any type for education, training or occupation, the risk of poverty, the state of health of the population depending on the level of education, the employment rate, unemployment rate etc.

\section{Results}

In this article we proposed that principal objective to identify position it had the education system in Romania, in so far as is necessary to ensure equity and efficiency in education by reference to its own targets but also by comparison with other education systems in the EU. The premise that we are leaving is that equity and effectiveness in education are two dimensions complementary: a high level of equity shall entail and a high efficiency. Although it can be influenced by a number of special features of the education system (its structure, type of organization, the content of education etc.) the effectiveness in education cannot be achieved in conditions of inequitable. With regard to the education system in Romania, we should expect a low level of equity and, consequently, and at a low efficiency of the latter.

\section{Discussion}

Complementarity of the two dimensions of the educational system - equity and efficiency - is supported in a first stage of data that must we use to assess:

- data reflecting the results achieved by students in the school to assess internal equity and efficiency; - data reflecting the impact that it has education on the level of living of the population, the type of occupation, the level of income, socio-economic situation of the household which belongs to the individual etc. to assess equity and external effectiveness of the educational system.

To highlight internal degree of equity of a system of education is the most frequently used the indicator "minimum level of knowledge". In general the minimum level of knowledge means holding those knowledge, skills, skills which not only protects organization/society man which they belong the additional costs, but rather, allow even obtaining positive effects on health, cooperation and cooperation, as regards compliance with the rules, to the standards governing the company etc. 
(Marinescu, 2001:38) When you discuss minimum level of knowledge to be learned by an individual, GERESE team is of the opinion that "whatever characteristics of the individual or social for a start, education systems have an obligation to act necessary means to ensure that all to acquire those powers be considered for the development of each and of the company as a whole". (Hutmacher et Bottani, coord., 2005:110)

Table 1. The percentage students located below the minimun threshold of knowledge(\%)

OCDE

Belgium

Bulgaria

Czech Republic

Denmark

Germany

Estonia

Irland

Greece

Spain

France

Croatia

Italy

Cyprus

Latvia

Lithuania

Luxembourg

Hungary

Malta

Netherlands

Austria

Poland

Romania

Slovenia

Slovakia

Finland

Sweden

United Kingdom

Iceland

Norway

Switzerland

Former Yug.Rep.of Macedonia

Turkey

\begin{tabular}{|c|c|c|}
\hline 2000 & 2008 & 2009 \\
\hline 21,3 & 24,1 & 20 \\
\hline 19 & 19,44 & 17,7 \\
\hline 40,3 & 51,1 & 41 \\
\hline 17,5 & 24,8 & 23,1 \\
\hline 17,9 & 16 & 15,2 \\
\hline 22,6 & 20 & 18,5 \\
\hline : & 13,6 & 13,3 \\
\hline 11 & 12,1 & 17,2 \\
\hline 24,4 & 27,7 & 21,3 \\
\hline 16,3 & 25,7 & 19,6 \\
\hline 15,2 & 21,7 & 19,8 \\
\hline 18,9 & 26,4 & 21 \\
\hline : & : & : \\
\hline 30,1 & 21,2 & 17,6 \\
\hline : & 25,7 & 24,3 \\
\hline 35,1 & 22,9 & 26 \\
\hline 22,7 & 20,6 & 17,6 \\
\hline : & : & : \\
\hline 9,5 & 15,1 & 14,3 \\
\hline 19,3 & 21,5 & 27,5 \\
\hline 23,2 & 16,2 & 15 \\
\hline 26,3 & 24,9 & 17,6 \\
\hline 41,3 & 53,5 & 40,4 \\
\hline : & 16,5 & 21,2 \\
\hline : & 27,8 & 22,3 \\
\hline 7 & 4,8 & 8,1 \\
\hline 12,6 & 15,3 & 17,4 \\
\hline 12,8 & 19 & 18,4 \\
\hline : & 21,5 & 22,5 \\
\hline 14,5 & 20,5 & 16,8 \\
\hline : & 32,2 & 24,5 \\
\hline 22,1 & 14,3 & 15,6 \\
\hline 17,5 & 22,4 & 14,9 \\
\hline
\end{tabular}

Source: Report on education in the EU - the data from the assessments PISA (: no data available) 
International program of evaluating knowledge, PISA, uses a scale of assessment divided into 7 levels, each level ii corresponds to a specific set of skills, knowledge in which the school is required to deal with it. All those who are located at level 2 or below this level are considered as students who do not have the minimum level of education, powers enabling them socio-professional integration.

From the point of view of PISA, this category of students should represent an alarm signal for the school system and to the society which they belong because they do not possess those powers enabling them in the future to participate in a manner efficient and productive in the life of society (PISA 2009:40).

We notice that the best results are recorded by the education system in Finland and the lowest by the education system in Romania. (Table 1). This means that a significant part of pupils in Romania will not be able to meet requirements of society and the economy if leave the education system it is essential to complete the compulsory education.

Table 2 Young people not in employment and not in any education and training by educational attainment (\%)

\begin{tabular}{|c|c|c|}
\hline & 2007 & 2013 \\
\hline EU-28 & 13,2 & 15,9 \\
\hline EU-27 & 13,2 & 15,8 \\
\hline Belgium & 13,0 & 14,9 \\
\hline Bulgaria & 20,3 & 25,7 \\
\hline Czech Republic & 11,6 & 12,8 \\
\hline Denmark & $5,3(b)$ & 7,5 \\
\hline Germany & 11,6 & 8,7 \\
\hline Estonia & 11,5 & 14,3 \\
\hline Irland & 11,9 & 18,6 \\
\hline Greece & 15,5 & 28,9 \\
\hline Spain & 13,1 & 22,8 \\
\hline France & 12,6 & $13,8(b)$ \\
\hline Croatia & 12,8 & 20,9 \\
\hline Italy & 18,9 & 26,0 \\
\hline Cyprus & 10,3 & 20,4 \\
\hline Latvia & 13,7 & 15,6 \\
\hline Lithuania & 10,1 & 13,7 \\
\hline Luxembourg & 7,3 & 7,2 \\
\hline Hungary & 15,3 & 18,8 \\
\hline Malta & 13,7 & 11,1 \\
\hline Netherlands & 4,9 & 7,1 \\
\hline Austria & 8,9 & 8,3 \\
\hline Poland & 14,4 & 16,2 \\
\hline Portugal & 12,7 & 16,7 \\
\hline Romania & 14,8 & 19,6 \\
\hline Slovenia & 8,2 & 12,9 \\
\hline Slovakia & 16,9 & 19,0 \\
\hline Finland & 8,4 & 10,9 \\
\hline Sweden & 7,9 & 7,9 \\
\hline United Kingdom & $12,9(b)$ & 14,7 \\
\hline
\end{tabular}


The result of the test PISA confirmed in the medium and long term, the adverse effects of low level of internal equity of the educational system: students who are not to be found in the system of education and training but not on the labor market is one of the highest in Romania. What's more, over the period of time that has elapsed since the economic crisis start in 2007 and last year the share this section of the population has increased by almost $5 \%$. In Member States where the education system is characterised by a higher level of internal equity, this percentage has remained the same (Sweden) or increased less than in the same period of time (Finland, for example).

In any society there are differences between individuals with regard to the level of income, living conditions, the type of occupation etc. These differences must, if not removed by school, then reduced influence school on the progress of their students. Upon completion of any level of education to the individual's social origin should not influence its chances to integrate social and occupational. We are talking in this case about the ability of the educational system to prove effectively - external efficiency.

Table 3 "The effect-school" on students' performance variation(\%)

Variation in inter-school students' Variation in intra-school performance

OCDE

Belgium

Bulgaria

Czech Republic

Denmark

Germany

Estonia

Irland

Greece

Spain

France

Croatia

Italy

Latvia

Lithuania

Luxembourg

Hungary

Malta

Netherlands

Austria

Poland

Romania

Slovenia

Slovakia

Finland

Sweden

\section{1,7}

61,7

74,1

49

13,1

68

18

32,4

54,8

19,5

W

46,7

77,3

21,5

16,1

61,6

67,5

59

64,5

18,3

29,6

46,8

47,8

34,5

7,7

21,7
64,5

55,8

74,3

51,1

69,4

44,9

64,6

80,4

64,2

69,8

W

51,6

47,2

59,9

60

79,7

33,7

32,3

51,4

79,3

59,9

44,2

35,8

52,7

80,7

95,7 
United Kingdom

Iceland

Norway

Turkey
32

15,6

10,1

75,4
77,2

94,5

87,7

37,5

Source: PISA 2009: 187 (I have selected only the data for the countries States UE) * $\mathrm{W}=$ no data available

PISA data shows that, for more than half of the students school of learning proves to be of great importance in the evolution of their education. At the level of all systems of education in the EU this type of factor - "the factor-school" - he didn't make their presence felt but act differently. In some states is even stronger among the difference between schools (Belgium, Bulgaria, Austria etc.) while in some of the others differences in the same schools are increasing concerns (Iceland, Finland, Luxembourg etc.) In the case of Romania, the differences between students are picked out at inter-school than intra-school. But,regardless of the situation - either that we are talking about the differences within the same school or differences between schools - conclusion is that education system in which this type of variation is high is a system with a low internal efficiency.

Between the level of education reached by a person and the level of education of the latter has always been a direct relationship: the higher the level of education is higher the chances of having an occupation which is safer, more well paid, with a level atfrom prestige are larger. On the other hand, it is also one of the main reasons for which individuals allocate time and money education.Such investment requires and risks: the diplomas, even when evidence testify to the completion of a high level of education, does not guarantee than access to competition for employment, not to get him.

Table 4 The employment rate on the basis of the highest level of education reached(\%)

$$
\text { ISCED 0-2 ISCED 3-4 ISCED 5-8 }
$$

\section{Eu-28}

EU-27

Belgium

Bulgaria

Czech Republic

Denmark

Germany

Estonia

Irland

Greece

Spain

France

Croatia

Italy

Cyprus

Latvia

Lithuania

Luxembourg

Hungary

Malta
43,9

43,8

37,5

27,8

22,0

54,3

53,2

35,5

35,4

38,9

43,2

42,9 (b)

42,2

25,6

40,5

31,7

17,1

43,2

27,2

48,8
67,9

67,7

65,3

63,6

72,4

77,2

76,9

69,7

60,7

46,9

55,2

$66,3(\mathrm{~b})$

62,6

51,9

62,4

65,6

63,0

65,3

63,7

68,3

\section{1,7}

81,7

81,0

80,7

82,5

86,1

87,5

82,3

79,2

68,2

74,1

$81,4(b)$

75,7

74,2

76,2

84,2

87,6

82,9

78,9

86,6 
Netherlands

Austria

Poland

Portugal

Romania

Slovenia

Slovakia

Finland

Sweden

United Kingdom

Iceland

Norway

Switzerland

Former Yug.Rep.of Macedonia

Turkey

Source: Eurostat, 2014

$\begin{array}{lll}58,1(\mathrm{~b}) & 76,9(\mathrm{~b}) & 87,4(\mathrm{~b}) \\ 48,3(\mathrm{~b}) & 77,1(\mathrm{~b}) & 85,9(\mathrm{~b}) \\ 22,4 & 61,6 & 82,3 \\ 55,2 & 64,6 & 76,7 \\ 42,1 & 64,0 & 81,7 \\ 33,7 & 62,9 & 82,4 \\ 15,8 & 64,6 & 74,7 \\ 39,7 & 65,6 & 83,8 \\ 45,5 & 80,3 & 87,3 \\ 53,4 & 71,7 & 83,9 \\ 71,5 & 83,8 & 90,0 \\ 44,0 & 52,4 & 73,7 \\ 62,6 & 80,0 & 88,8 \\ 56,1 & 79,5 & 88,7 \\ 28,4 & 52,4 & 67,5\end{array}$

Eurostat data shows that in all the countries in which they have been collected data, persons who have a high level of education have a rate higher than employment compared with people with low level of education. This means that education systems are characterised by a high level of foreign equity. Difference between states in terms of employment rates depending on the level of education achieved is due to the special characteristics of the educational system in terms of the mode of organization, structure, content type etc. but and the extent of socio-economic development. But, even under the conditions in which the level of socio-economic development of Romania is much lower than that of Germany or Great Britain, for exemple, we notice that the level of education achieved is as important and for Romanians and Germans or British.

Occupation it is very important not only for an individual, but also for the household which he/she belongs to that means a source of income by which it cover expenses with different services between which and education.

Table 5 Risk of poverty rate by level of education(\%)

\section{EU-27}

Belgium

Bulgaria

Czech Republic

Denmark

Germany

Estonia

Irland

Greece

Spain

France

\section{ISCED 0-2} 15,0(e) 15,1 35,5

9,5

9,4

23,5

17,8

16,5

12,3
ISCED 3-4

ISCED 5-6

$7,9(\mathrm{e})$

5,6

6,4

3,5

3,5

10,5

11,6

7,7

8,2 $3,7(\mathrm{e})$

2,1

1,7

1,8

4,8

6,8

1,7

3,6

6,2 
Croatia

Italy

$\begin{array}{lll}15,4 & 7,1 & 2,3 \\ 19,0 & 3,9 & 0,8 \\ 15,4 & 8,9 & 2,0 \\ 11,1 & 6,1 & 3,7 \\ 8,6 & 4,3 & 1,2 \\ 14,2 & 5,8 & 1,0 \\ 12,9 & 6,6 & 3,0 \\ 8,4 & 6,1 & 2,3 \\ 13,0 & 4,1 & 2,9 \\ 17,5 & 9,9 & 1,6 \\ 12,8 & 6,8 & 2,4 \\ 28,5 & 10,0 & 0,7 \\ 15,5 & 6,2 & 1,2 \\ 15,9 & 5,3 & 2,8 \\ 16,0 & 8,3 & 2,1 \\ 11,0 & 2,9 & 2,7 \\ 11,7 & 8,4 & 1,9 \\ 0,6 & 2,9 & (\mathrm{z}) \\ 10,5 & 3,1 & 6,1 \\ & & \end{array}$

Cyprus

Latvia

Lithuania

Luxembourg

Hungary

Malta

Netherlands

Austria

Poland

Romania

Slovenia

Slovakia

Finland

Sweden

United Kingdom

Iceland

10,5

Source: Eurostat, 2014 (e: estimation)

It is found that, according to Eurostat data, as well as on the whole, in the EU-28, as well as the level of education is higher, the risk of poverty is further reduced.

In current society, knowledge-based, it is not sufficient to be a graduate of a level as well as higher education, but also requires regular updating of the knowledge, skills, competences. Changes in the level of science and technology are so frequent and is conducted at a fast that what and endorse a student at the beginning of a school cycle, can become exceeded at its completion. Participation in courses of lifelong learning, in the learning process throughout the life is a solution to avoid marginalisation social and economic situation. In these circumstances, the education systems will be required to prepare individuals who possess the ability to learn by themselves, to adapt to changes.

Since 2005 the EU is conducted at the Adult Education Survey (AES) witch took part 20 EU member states, EFTA and candidate countries. EU- wide average rate of adult participation in formal and non-formal education is $34,9 \%$, however, considered separatley, states participating in the survey have from 73\% in Sweden and 7\% in Romania.(AES, 2011:11) AES date confirms theories of social reproduction: the education level of person is higher the more likely it is to continue educational and vocational training or return to education and training system whernever deemed necessary. At EU-28 level, only $2 \%$ of adults who have a low level of education (ISCED 0-2) participating in formal education and training compared to $12 \%$ of type in the have level (ISCED 5-6). Such differences are maintained in each country participating in the investigation. In Romania, adults with low education participation records $0,2 \%$ the middle level (ISCED 3-4) by 3,5\% and those with high level of education (ISCED 5-6) records an attendance of 8,4\%.(AES, 2011:15)

All data provided in question and their analysis on the basis of the indicators belonging to various systems of indicators reveal the fact that, for a system of education is fair and a system of effective education. Although a large part of the differences between Member States, both those related to education systems as well as those which affects socioeconomic situation, is also reflected on the level of equity and efficiency in education, they do not influence complementarity between the two dimensions. With regard to the education system in Romania, analysis of the data confirmed hypothesis 
to where we started: the performance educational (internal and external efficiency of the system) are low compared with other EU states-28 and for the level of equity of internal and external system is reduced.

\section{References}

Bârzea, C. (coord.),(2005) Sistemul naţional de indicatori pentru educaţie, [online] disponibil la www.fiatest.ro/eqf/INDICATORI\%20NATIONALI\%20PENTRU\%20EDUCATIE\%20-Manual.pdf Becker, G. (1997), Capitalul uman, Bucureşti, Editura ALL

Bourdieu, P., Passeron, J.C., Învăţământ şi reproducţie socială, în Fred Mahler (coord.),,Sociologia educaţiei şi învăţământului. Antologie de texte contemporane de peste hotare" (1975), Bucureşti, Editura Didactică şi Pedagogică; Bottani, N., (2008), Le niveau d'huile, le moteur et la voiture: les enjeux d'une évaluation de la qualité de l'enseignement par les indicateurs în Revue Éducation \& Formation nr 78, novembre, [online] disponibil la http://ute3.umh.ac.be/revues; Herbaut , E. (2011), L'évaluation de l'équite scolaire: perspective nationales et internationales Revues Education \& formation n.80 decembre [online] at http://cache.media.education.gouv.fr/file/revue_80/29/8/Depp-EetF-2011-80evaluation equitescolaire-national-international_203298.pdf

Hutmacher, W., Bottani, N., - G.E.R.E.S, (2005) L'équité des systèmes éducatifs européens: un ensemble d'indicateurs, [online] at http://www.aspe.ulg.ac.be/equite/fichier/pdf/2005PDF FRANCAIS.pdf Marinescu, C., (2010), Educatia, perspectivă economică, București, Editura Economică Adult in formal Education:Policies and Practices in Europe, 2011, [online] at http://ecea.ec.europe/education/eurydice/thematic_reports?en.php

Eurostat, 2014, [online] at http://epp.eurostat.ec.europa.eu/portal/page/portal/statistics/search_database?_piref458_1209540_458_211810_211810. node_code=Ifsa_agaed

PISA 2009, Volume II- Analyse des résultats [online], diponibil la www.ocde.org/edu/pisa/2009

Programul OCDE - PISA [online] disponibil la www.edu.ro/index.php/articles/c826/

Rapport sur l'éducation dans l'UE: des progres, mais des efforts restent necessaires pour atteindre les objectifs, [online] at www. ec.europa.eu/education/news/news2900_fr.htm Résultats du PISA 2009: Surmonter le milieu social. L'égalité des chances et l'équite du randament de l'apprentissage. Vol II. [online] at

http://www.oecd.org/dataoecd/11/40/44455820.pdf 